Trakya Eğitim Dergisi

Cilt 10, Sayı 2

May1s 2020, 347-360

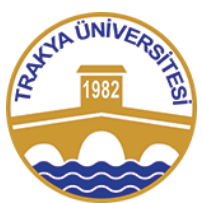

ISSN: $2630-6301$

Doi: $10.24315 /$ tred.618955

Araştırma Makalesi
Trakya Journal of Education

Volume 10, Issue 2

May 2020, 347-360

Yayına Kabul Tarihi:03.04.2020.

Research Article

\title{
Okullarda Örgütsel Sinizmin Yordayıcısı Olarak Lider-Üye Etkileșimi
}

\section{Leader-Member Exchange as a Predictor of Organizational Cynicism in Schools}

\section{Sedat ALEV ${ }^{1}$}

ÖZ: Bu çalışmada, okullarda lider-üye etkileșimi ve örgütsel sinizm arasındaki ilişkinin incelenmesi amaçlanmıştır. Çalışma ilişkisel tarama modelinde tasarlanmıştır. Araştırmanın örneklemini; 2018-2019 eğitim-öğretim y1lında Gaziantep'in Şahinbey ilçesinde görev yapan 363 ortaokul öğretmeni olușturmaktadır. Veriler, "Lider-Üye Etkileșimi Ölçeği" ve "Örgütsel Sinizm Ölçeği” aracılığ analizinde, SPSS programından yararlanılmıştır. Analizlerden elde edilen bulgulara göre; lider-üye etkileşimi ve örgütsel sinizm arasında negatif yönde bir ilişki bulunmaktadır. Regresyon analizi sonucunda, lider-üye etkileşiminin hem genel hem de duygu, mesleki saygı ve katkı alt boyutlarının örgütsel sinizmi negatif yönde yordadığı sonucuna ulaşılmıştır. Okullarda öğretmenlerin okul yöneticileri ile iletişim halinde olması, örgütsel sinizm davranıșlarının daha az gösterilmesini sağlayacaktır. Bu nedenle, öğretmen ve yöneticilerin güvene dayalı ilişkiler kurmaları önemlidir. Ayrıca bu süreçte öğretmenlerin de mesleki rollerinin gereklerini yerine getirmeleri, eğitim öğretimi geliştirmeye yönelik faaliyetlere katılım sağlamaları hem yöneticilerle hem de diğer meslektaşlarıyla güven, saygı ve sadakat temeline dayalı ilişkiler kurmaları önemlidir.

Anahtar sözcükler: Lider-üye etkileşimi, örgütsel sinizm, ortaokul, öğretmen

\begin{abstract}
The purpose of this study is to investigate the relationship between leader-member exchange and organizational cynicism in schools. The research was designed as a correlational survey model. The sample of the study consists of 363 secondary school teachers working in Şahinbey district of Gaziantep in 20182019 academic year. Data were collected through "Leader-Member Exchange Scale" and "Organizational Cynicism Scale". SPSS program were used to analyze the data. As a result of the research, there is a negative correlation between leader-member exchange and organizational cynicism. The results of regression analysis, both general and emotion, contribution, and professional respect subdimensions of leader-member exchange, negatively and significant predict organizational cynicism. In schools, the communication of teachers with school administrators will make the behaviors of organizational cynicism less visible. Therefore, it is significant that teachers and administrators establish trust-based relationships. Besides in this process, it is important for teachers to fulfill the requirements of their professional roles, to participate in activities to develop education and to establish relationships based on trust, respect and loyalty with both managers and other colleagues.
\end{abstract}

Keywords: Leader-member exchange, organizational cynicism, secondary school, teacher

\section{Bu makaleye atıf vermek için:}

Alev, S. (2020). Okullarda örgütsel sinizmin yordayıcısı olarak lider-üye etkileşimi. Trakya Eğitim Dergisi, 10(2), 347-360.

Cite this article as:

Alev, S. (2020). Leader-member exchange as a predictor of organizational cynicism in schools. Trakya Journal of Education, 10(2), $347-360$

\section{EXTENDED ABSTRACT}

\section{Introduction}

In order to achieve organizational goals effectively, managers and employees need to communicate and interact all the time. In this case, leader-member exchange, which indicates the level and quality of communication between the managers and employees, is important in the evaluation of the communication process (Deluga, 1994). Leader-member exchange is defined as a relationship of social change based on trust, respect and loyalty, apart from formal work relations between leader and member (Yu and Liang, 2004). Improving the quality and level of leader-member exchange will contribute to higher performance of employees and to reduce the factors that are thought to affect their performance negatively. Thus, it can be stated that organizational cynicism, which adversely affects employee performance and is expressed as negative attitudes and beliefs towards the organization (Dean, Brandes and Dharwadkar, 1998), is one of the negative factors that can be reduced by developing leader-member exchange. Therefore, it can be argued that improving the quality of leader-member interaction will reduce the cynicism behaviors.

\footnotetext{
${ }^{1}$ Dr., Milli Eğitim Bakanlığı, Gaziantep/Türkiye, sedat_alv@hotmail.com, ORCID: 0000-0003-4506-4756
} 
In schools, it is significant that the interaction among teachers and administrators is high level. Because this situation will affect the educational activities positively. Besides, it is thought that factors such as interacting with school administrators, taking an active role in school-related activities and participating in decision-making process are effective in the positive perceptions of teachers about leader-member exchange. It is important to determine the relationship between leader-member exchange and organizational cynicism in schools and discuss the results to be obtained in the context of education. Therefore, it is purposed to investigate the relationship between leader-member exchange and organizational cynicism in schools. In accordance with this aim, answers to the following questions were sought:

1. What are the teachers' leader-member exchange and organizational cynicism perception levels?

2. Is the relationship between leader-member exchange and organizational cynicism statistically significant?

3. When personal variables (gender, age and seniority) are taken under control, is the leadermember exchange a significant predictor of organizational cynicism?

4. When personal variables (gender, age and seniority) are taken under control, are the subdimensions of leader-member exchange, emotion, contribution, loyalty, and professional respect significant predictors of organizational cynicism?

\section{Method}

This study was conducted with the purpose of determining the relationship between leadermember exchange and organizational cynicism using a quantitative research method and correlational survey model. The sample of the study consists of 363 teachers working in secondary schools in Şahinbey district of Gaziantep province in 2018-2019 academic year. It was decided that 363 teachers are sufficient for the sample group when the confidence interval of $95 \%$ and statistical significance level of $\alpha=.05$ were taken into consideration (Field, 2009) making use of the formula developed for determining the magnitudes with a predetermined population.

Of the teachers in the sample group, 146 male (40.2\%) and 217 female (59.8\%) teachers were seen. 160 of the teachers are married (44.1\%) and 203 are single (55.9\%). With regard to age groups, 240 of them $(66.1 \%)$ were between the ages of $21-30,130(28.4 \%)$ between the ages of $31-40$ and 20 $(5.5 \%)$ were 41 and above. In terms of seniority, 294 (81\%) of teacher had a seniority of 1-9 years, 62 (17.1\%) $10-19$ years, and 7 (1.9\%) 20 years and above. The number of teachers with a bachelor's degree is $301(82.9 \%)$ while the number of teachers with a master's degree is $62(17.1 \%)$.

The scale form used in the study was comprised of three sections. The first section contains the personal information of the teachers; whereas the second section includes the "Leader-Member Exchange Scale" comprised of 12 items, the third section contains the "Organizational Cynicism Scale" comprised of 13 items. All of the scales were 5-point Likert type scales with responses as, "(1) I certainly do not agree”, "(2) I do not agree", "(3) I partially agree", "(4) I agree” and "(5) I completely agree".

The scale of leader-member exchange, developed by Liden and Maslyn (1998) is comprised of a total of 12 items and 4 sub-dimensions. Cronbach's Alpha of the overall scale was 0.932. The fourdimensional structure of the scale was verified for the study sample group as a result of confirmatory factor analysis (CFA). Fit values were identified as: $\chi^{2}=146.180, \chi^{2} / \mathrm{df}=3.110, \mathrm{p}=0.00$, GFI $=0.941$, $\mathrm{NFI}=0.959, \mathrm{IFI}=0.972$, TLI=0.960, CFI $=0.972$, RMSEA=0.076, RMR $=0.038$. These obtained values are at acceptable levels (Hu and Bentler, 1999; Kline, 2011; Schermelleh-Engel, Moosbrugger and Müller, 2003). The scale of organizational cynicism, developed by Branders at al. (1999), adapted by Kalağan (2009) is comprised of a total of 12 items and three-dimension. Cronbach's Alpha of the overall scale was 0.909 . The three-dimensional structure of the scale was verified for the study sample group as a result of CFA. Fit values were identified as: $\chi^{2}=107.938, \chi^{2} / \mathrm{df}=2.768, \mathrm{p}=0.00$, GFI $=0.951$, $\mathrm{NFI}=0.959, \mathrm{IFI}=0.972$, TLI $=0.960, \mathrm{CFI}=0.972$, RMSEA $=0.076, \mathrm{RMR}=0.038$. These obtained values are at acceptable levels.

SPSS 22.0 was used for the calculation of descriptive statistics, correlation and regression analysis during the data analysis stage; whereas AMOS 23.0 software was used for CFA analysis. 


\section{Result and Discussion}

The findings of descriptive statistics indicate that teachers' leader-member exchange is partly at a high-level; whereas organizational cynicism is partly at a low-level. According to the results of correlation analysis; there is a negative correlation between leader-member exchange and organizational cynicism. According to the results of regression analysis, both general and subdimensions (except loyalty) of leader-member exchange, negatively and significant predict organizational cynicism.

Based on the results of the research, some suggestions can be made for both practitioners and researchers. It is important that school principals build trust-based relationships with teachers and create an environment in which teachers can express their thoughts comfortably. The relationship between leader-member exchange and organizational cynicism were determined by analyzing data collected from teachers in secondary schools. Research can also be conducted in different levels and largers samples. Studies with qualitative and mixed research design can be carried out. It is useful for school administrators to create a culture based on trust, encourage teachers to do activities that contribute to the development of the school, enable teachers to participate effectively in decision-making process and to make decisions and create an environment where they can express their thoughts comfortably.

\section{GİRiș}

Örgütsel amaçların etkin bir şekilde gerçekleştirilmesi için yöneticilerin ve çalışanların, sürekli olarak iletişim ve etkileşim halinde bulunmaları gerekmektedir. Söz konusu bu durumda iletişim sürecinin değerlendirilmesinde, yönetici ve çalışanlar arasındaki iletişimin düzeyini ve niteliğini gösteren lider-üye etkileşimi önem kazanmaktadır (Deluga, 1994). Yu ve Liang'a (2004) göre, liderüye etkileşimi, lider ile üye arasında gerçekleşen ve resmi iş ilişkilerinin dışında, sadakat, saygı ve güven temeline dayanan bir ilişki olarak tanımlamaktadırlar. Liderin üyelere karşı eşit şekilde davrandığını ileri süren diğer liderlik yaklaşımlarından farklı olarak, lider-üye etkileşimi teorisinde, liderin her üyeyle farklı düzeyde ilişkisi olduğu varsayımı ileri sürülmektedir (Liden ve Maslyn, 1998). Bu konuda Karcıoğlu ve Kâhya (2011) liderin her üyeye aynı şekilde davranmayacağını ve ilişkisinin niteliğinin farklı olacağını ifade ederken; benzer şekilde Martin, Thomas, Charles, Epitropaki ve McNamara (2005) da liderin etkileşimde bulunduğu üyelerle ilişki düzeylerinin farklılaşabileceğini belirtmiştir. Lider-üye etkileşimi teorisine göre, liderin bazı üyelerle olan ilişkisinin niteliği zamanla artarken, bazı ilişkiler ise daha resmi ve geleneksel düzeyde kalmaktadır (Burton, Sablynski ve Sekiguchi, 2008). Loi, Chan ve Lam'ın (2014) ifade ettiği gibi, lider ve üye arasındaki etkileşimin yüksek düzeyde olması güvene dayalı ilişkilerin kurulmasını sağlarken; etkileşimin düşük düzeyde olması ise ilişkilerin biçimsel ve denetim odaklı olmasına neden olmaktadır.

Alan yazında lider-üye etkileşimi; duygu, sadakat, katk1 (Dienesch ve Liden, 1986); güven, minnet, sayg1 (Graen ve Uhl-Bien, 1995); duygu, katk1, sadakat ve mesleki sayg1 (Liden ve Maslyn, 1998); güven, sadakat, dikkat, hoşgörü, beğenme ve karşıllklı destek (Schriesheim, Castro ve Cogliser, 1999) olmak üzere çeşitli alt boyutlarda ele alınmıştır. Bu araştırmada, araştırmacıların çoğunlukla kullandığg (Gürler, 2018; Kavuncu, 2019; Lee, 2005; Maslyn ve Uhl-Bien, 2001; Settoon, Bennett ve Liden, 1996) ve lider-üye etkileşimini duygu, katkl, sadakat ve mesleki saygı olmak üzere dört alt boyutta inceleyen Liden ve Maslyn'in (1998) sınıflandırması esas alınmıştır.

Duygu; duygusal etkileşim olarak da ifade edilmektedir. Lider ile üyenin birbirlerine karşı sempati duyması, samimi davranışlar sergilemesi ve karşılıklı etkileşimde bulunması bu boyut kapsamında ele alınmaktadır (Dienesch ve Liden, 1986). Okullarda yöneticilerin ve öğretmenlerin birlikte çalışma isteği, okul dışında da çeşitli paylaşımlarda bulunmaları, olumlu ilişkiler kurmaları ve söz konusu bu ilişkileri geliştirerek devam ettirmeleri bu boyut kapsamında değerlendirilebilir.

Katkl; lider-üye etkileşimi esnasında, ortak amaç doğrultusunda doğrudan ya da dolaylı olarak ortaya konulan eylemlerin miktarı, niteliği ve yönü hakkındaki algılamaları içermektedir (Bolat, 2011). Başka bir deyişle katkı, ortak amaçlara yönelik her bir üyenin algılanan çalışmasıdır. Okullarda öğretmenlerin ve yöneticilerin eğitim-öğretim faaliyetlerinin gerçekleştirilmesi sürecinde ortak amaçlar doğrultusunda süreci geliştirmeye yönelik performans göstermeleri bu boyuta örnek olarak verilebilir.

Sadakat; lider-üye etkileşiminin gelişiminde ve bu etkileşimin devam ettirilmesinde önemli rol oynamakta (Kaşı, 2009), lider ve üyenin birinin aldığı kararı diğerinin onaylamasını, saygı duymasını, 
destek olmasını ve savunmasını kapsamaktadır (Göksel ve Aydıntan, 2012). Çünkü hem liderini destekleyen, işlerini kolaylaştıran üyelerin olması hem de üyelerini destekleyen ve haksızlıklara karşı savunan liderlerin olması, lider-üye etkileşiminin devam ettirilmesi için önemlidir. Öğretmenlerin yöneticilerini desteklemeleri ve alınan kararların uygulanması aşamasında aktif rol almaları, yöneticilerin ise öğretmenlerin işlerini kolaylaştırmaları, destek olmaları ve haksızlıklar karşısında onları savunmaları sadakat alt boyutu kapsamında ele alınabilir.

Mesleki saygı, işle ilgili konularda lider ve üyenin karşılıklı olarak yeterliklerine yönelik algılarla ilgilidir (Liden ve Maslyn, 1998). Bu algılar, geçmiş deneyimlere, diğer bireyler üzerinde oluşturulan izlenimlere ve alınan ödüllere dayanmaktadır (Baş, Keskin ve Mert, 2010). Eğitim bağlamında değerlendirildiğinde, öğretmenlerin okul yöneticilerinin uzmanlık gücüne ve mesleki yeterliklerine güvenmeleri, okul yöneticilerinin ise öğretmenlerin mesleki anlamda yeterli oldukları izlenimi edinmeleri, aralarındaki etkileşimi güçlendirerek mesleki anlamda birbirlerine saygı duymalarını sağlayacaktır. Nitekim Alev'in (2018) ifade ettiği gibi gerek maddi kazanımlar elde etmek gerekse sosyal statülerini artırmak ve saygın biri haline gelmek için çeşitli şekillerde kendilerini ispatlamaya çalışan öğretmenler, bu amaç doğrultusunda performans sergileyerek kendileriyle ilgili olumlu bir izlenim oluşturma çabası içerisine girmektedirler. Bu bağlamda, çevresi üzerinde olumlu izlenimler oluşturan öğretmenlerin, mesleki anlamda daha çok sayg1 görecekleri düşünülmektedir.

Brower, Schoorman ve Tan (2000), lider-üye etkileşiminin yüksek düzeyde olmasının, üyelerin performansını arttırdığını belirtmektedir. Etkileşimin kalitesinin ve düzeyinin yükseltilmesi, çalışanların daha yüksek performans göstermelerine ve performanslarını olumsuz yönde etkileyebileceği düşünülen unsurların azaltılmasına katkı sağlayacaktır. Bu nedenle, çalışanların performanslarını olumsuz yönde etkileyen, örgütte yaşanan hayal kırıklıklarının ve adil olmayan süreçlerin bir sonucu (Wilkerson, Evans ve Davis, 2008), örgüte karşı gösterilen olumsuz tutum ve inanç (Dean, Brandes ve Dharwadkar, 1998) şeklinde ifade edilen örgütsel sinizmin, lider-üye etkileşiminin geliştirilmesiyle azaltılabilecek olumsuz unsurlardan biri olduğu ifade edilebilir.

Örgütsel sinizm, çalışanların örgütün dürüstlükten yoksun olduğunu düşünmeleri sonucunda (Johnson ve O'Leary-Kelly, 2003), ahlak ve adaletle ilgili beklentilerin karşılanmadığı durumlarda ortaya çıkmaktadır (Karacaoğlu ve İnce, 2013). Sinizm davranışı gösteren çalışanlar, yaşanan küçük sorunların dahi çözüme kavuşturulamayacağını ve bu nedenle de herhangi bir çaba göstermenin gerekli olmadığını düşünmektedirler (Nartgün ve Kartal, 2013). Dolayısıyla sinizmin oluşmasında, örgüte karş1 güven eksikliğinden kaynaklı olarak, olumsuz bir tutum geliştirilmesi söz konusudur. Bu olumsuz tutumlar ise bilişsel boyutta, duyuşsal boyutta ve davranışsal boyutta ele alınmaktadır (Dean, Brandes ve Dharwadkar, 1998). Bilişsel sinizm, çalışanların bulundukları kurumda yapılan iş ve işlemlerde dürüst ve adil davranılmadığına yönelik inançlardır. Bu inanca sahip olan çalışanlar, kurum içi ilişkilerin çıkara dayalı olduğu, çıkarları gerçekleştirmek için samimiyet, doğruluk ve dürüstlük gibi değerlere aykırı davranışlarda bulunulabileceği görüşündedirler (Brandes, 1997; Kalağan, 2009; Kalağan ve Aksu, 2010). Sinizm bilişsel olduğu kadar hissedilen ve duygularla ifade edilen bir olgu olarak da kabul edilmektedir (Dean, Brandes ve Dharwadkar, 1998). Duyuşsal sinizm, çalışanların yapılan işleri önemsiz görmesi ve örgüte karşı güvensizlik, öfke, saygısızlık gibi negatif duygusal tepkiler vermesidir (Abraham, 2000; Andersson ve Beteman, 1997). Davranışsal sinizm ise, çalışanların çevresindeki kişilere örgütle ilgili olumsuz eleştirilerde bulunması, uygulamalardan şikayetini dile getirmesi şeklinde ifade edilmektedir (Brandes, 1997; Dean, Brandes ve Dharwadkar, 1998). Kisaca ifade etmek gerekirse, örgütsel sinizmde, çalışanlar örgüt içerisinde dürüst ve adil davranılmadığ inancına sahip olduğu zaman örgüte karşı olumsuz duygular beslemekte, bunu tutum ve davranışlarıyla çevresindekilere yansitmaktadırlar.

Örgütsel sinizm konusunda yapılan araştırmalarda, örgütsel sinizmin, örgütsel vatandaşlık (Abraham, 2000; Anderson ve Bateman, 1997), örgütsel bağlllık (Reichers, Wanous ve Austin, 1997) ve örgütsel özdeşleme (Polat ve Meydan, 2010) gibi olumlu örgütsel çıtılarla negatif yönde ilişkisi olduğu; işe yabancılaşma (Abraham, 2000) ve duygusal tükenmişlik (Johnson ve O'Leary-Kelly, 2003) gibi olumsuz çıktılarla ise pozitif yönde ilişkiye sahip olduğu bulgusu elde edilmiştir. Dolayısıyla Neves'in (2012) de belirttiği gibi örgütsel sinizm, örgütün işleyişini olumsuz yönde etkileyebileceği için çözülmesi gereken bir sorun olarak kabul edilmektedir.

Okullarda lider-üye etkileşimi, yönetici ve öğretmenler arasında gerçekleşmektedir. Okul ortamında lider-üye etkileşiminin önemine dikkat çeken Cerit (2012), yönetici ve öğretmenler arasındaki etkileşimin yüksek olmasının, karşılıklı güven ortamı oluşturacağını, bilgi alışverişini 
arttıracağını ve buna bağlı olarak öğretmenlerin okulla ilgili yapılacak faaliyetlerde aktif rol alacaklarını ve rollerinin gereklerini yerine getirmek için daha fazla çaba göstereceklerini ifade etmiştir. Bu ifadeden anlaşılacağı üzere, yöneticilerin ve öğretmenlerin etkileşim içerisinde olması eğitim-öğretim faaliyetlerini olumlu yönde etkileyerek öğretmenlerin okula yönelik olumlu bir tutum geliştirmelerini sağlamaktadır. Okula yönelik geliştirilen bu olumlu tutum sonucunda ise öğretmenlerin sinizm davranışları azalmaktadır. Çünkü okul yönetiminin aldığı kararlarda ve uygulamalarda şeffaf olmadığını düşünen öğretmenlerin, güven düzeyi azalmakta ve sinizm davranışları artmakta (Helvacı ve Çetin, 2012); öğretmenlerin okula ilişkin olumsuz tutum ve duyguya sahip olmaları nedeniyle de performanslarında düşüş meydana gelmektedir (Sağır ve Oğuz, 2012).

Öğretmenlerin performanslarında meydana gelebilecek azalmanın hiç şüphesiz eğitim-öğretim faaliyetlerine yansıması da olumsuz yönde olacaktır. Bu nedenle, lider-üye etkileşiminin kalitesinin yükseltilmesinin öğretmenlerin sinizm davranışlarını azaltacağı ileri sürülebilir. Bu ifadeyi destekler nitelikte, alan yazında sinizmin genellikle örgütsel yapıya ve lidere yönelik olarak gösterildiği (Andersson ve Bateman, 1997; Brandes, 1997; Guastello, Rieke, Guastello ve Billings, 1992; Stanley, Meyer ve Topolnytsky, 2005; Wanous, Reichers ve Austin, 1994) ve lider-üye etkileşiminin niteliğinin düşüklüğünün sinizmin örgütsel nedenleri arasında yer aldığı ifade edilmiştir. Konuyla ilgili olarak Bommer, Rich ve Rubin (2005) tarafından yapılan araştırmada lider-üye etkileşiminin yüksek olmasının çalışanların sinizm davranışlarını azalttığı sonucuna varılmıştır. Cole, Brunch ve Vogel (2006) yöneticilerin çalışanlara destek olduğu ve güvene dayalı ilişkiler kurduğu zaman sinizm davranışlarının daha az görüleceğini ifade ederken; Davis ve Gardner (2004) ise, örgütsel ortamda adalet, dürüstlük, doğruluk ve samimiyetin olmadığı durumlarda lider-üye etkileşiminin düşük olacağını ve bunun sonucunda sinizm davranışlarının daha fazla sergileneceğini ifade ederek, lider-üye etkileşiminin örgütsel sinizmi azaltıcı bir rolü olduğuna atıfta bulunulmuştur.

Yönetici ve öğretmenler arasında etkileşimin yüksek olması durumunda, karşılıklı güven ve bilgi alışverişi daha fazla olmakta, öğretmenler rollerinin gerekliliklerini yerine getirmekte ve bu durum okulun başarısına katkı sağlamaktadır (Cerit, 2012). Okullarda lider-üye etkileşimi ile örgütsel sinizm ilişkisinin belirlenerek, elde edilecek sonuçların eğitim bağlamında tartışılması önemli görülmektedir. $\mathrm{Bu}$ bağlamda, araştırmada yöneticiler ve öğretmenler arasındaki etkileşimin, öğretmenlerin örgütsel sinizm davranışları ile ilişkisi incelenmiştir. Bu doğrultuda, araştırmada yanıt aranan sorular aşağıda yer almaktadir.

1. Öğretmenlerin lider-üye etkileşimi ve örgütsel sinizm algı düzeyleri nedir?

2. Lider-üye etkileşimi ve örgütsel sinizm arasındaki ilişki istatistiksel olarak anlamlı mıdır?

3. Kişisel değişkenler (cinsiyet, yaş ve kıdem) kontrol altına alındığında, lider-üye etkileşimi, örgütsel sinizmi anlamlı bir şekilde yordamakta mıdır?

4. Kişisel değişkenler (cinsiyet, yaş ve kıdem) kontrol altına alındığında, lider-üye etkileşiminin duygu, katkı, sadakat ve mesleki saygı alt boyutları, örgütsel sinizmi anlamlı bir şekilde yordamakta midir?

\section{YÖNTEM}

\subsection{Araştırmanın Modeli}

Lider-üye etkileşimi ile örgütsel sinizm ilişkisini tespit etmek amacıyla yapılan araştırmada, iki veya ikiden fazla değişken arasındaki ilişkinin varlığının ve yönünün belirlemesi amaçlandığı (Balc1, 2016; Karasar, 2015) ilişkisel tarama modeli kullanılmıştır. Bu modelde tasarlanan çalışmalarda, değişkenler arasındaki ilişkiler tespit edildikten sonra, değişkenler arasında neden-sonuç ilişkisi olabileceğine yönelik tahminlerde bulunulmaktadır. Bu kapsamda çalışmada, lider-üye etkileşiminin örgütsel sinizmi yordama düzeyine bakılmıştır.

\subsection{Evren ve Örneklem}

Araştırma evreni, 2018-2019 eğitim-öğretim yılında, Gaziantep'in Şahinbey ilçesinde bulunan ortaokullardan oluşmaktadır. Örneklem ise, küme örnekleme yöntemiyle tesadüfi olarak seçilen 24 ortaokulda görev yapan 363 öğretmenden oluşmaktadır. Ölçeklerin yer aldığ 1 form, geri dönüş oran1 dikkate alınarak 450 öğretmene dağıtılmıştır. Dağıtılan ölçeklerin \% 80.66'sı geçerli kabul edilerek, 
analizler 363 ölçek üzerinden yapılmıştır. Bu sayının $\% 95$ güven düzeyi ve $\alpha=.05$ anlamlılık düzeyi için yeterli olduğuna karar verilmiştir (Field, 2009).

Araştırmaya katılan öğretmenlerin $(\mathrm{n}=146) \% 40.2$ 'si erkek, $(\mathrm{n}=217) \% 59.8$ 'i kadın; $(\mathrm{n}=160)$ \%44.1'i evli, (n=203) \%55.9'u ise bekâr öğretmenden oluşmaktadır. Öğretmenlerin, (n=240) \%66.1'i 21-30 arası, $(n=103) \% 28.4$ 'ü 31-40 arası, $(n=20) \% 5.5$ 'i ise 41 ve üzeri yaş aralığındadır. Kıdem bakımindan (n=294) \%81'i 1-9 y1l aras1, $(\mathrm{n}=62) \% 17.1$ 'i $10-19$ y1l aras1, $(\mathrm{n}=7) \% 1.9$ 'u ise 20 y1l ve üzeri kıdemdedir. Lisans mezunu öğretmenlerin sayıs1 $(n=301) \% 82.9$, lisansüstü öğretmenleri sayıs1 ise $(\mathrm{n}=62) \% 17.1$ 'dir.

\subsection{Veri Toplama Araçları}

Veriler, "Lider-Üye Etkileşimi Ölçeği” ve "Örgütsel Sinizm Ölçeği” aracıllğı ile toplanmıştır. Ölçeklerin her ikisi de 5'li Likert tipinde hazırlanmıştır. Ölçeklerde yer alan ifadeler, "Kesinlikle katılmıyorum (1)", "Katılmiyorum (2)", "Biraz kat1lyorum (3)", "Kat1lyorum (4)" ve "Tamamen katılıyorum (5)" biçiminde cevaplanmaktadır.

Liden ve Maslyn'in (1998) geliştirdiği Lider-Üye Etkileşimi Ölçeği, ilkokul ve ortaokul öğretmenleri örnekleminde, Öztürk (2015) tarafından Türkçeye uyarlama, geçerlik ve güvenirlik çalışmaları yapılmıştır. Toplam 12 maddeden ve 4 alt boyuttan (duygu, katkı, sadakat ve mesleki saygı) oluşmaktadır. Yapılan araştırmada, ölçeğin güvenirlik ve geçerlik çalışmaları tekrar yapılmıştır. Cronbach's Alpha Güvenirlik Katsayıs1, duygu alt boyutunda .888, katk1 alt boyutunda .915, sadakat alt boyutunda .774 , mesleki saygı alt boyutunda .927 , geneli için ise .932 olarak belirlenmiştir. Ölçeğin orijinali teorik temeller doğrultusunda geliştirildiği, maddelerin ilişkili olduğu boyutlar önceden bilindiği ve öğretmen örnekleminde daha önce uygulandığı için tekrar açımlayıcı faktör analizi yapılmamıştır. Ölçeğin yapı geçerliği için doğrulayıcı faktör analizi (DFA) yapılmıştır. Model uyum değerlerini arttırmak için yapılan modifikasyon sonucunda, LÜE5 ve LÜE6 maddelerinin hata terimleri arasına kovaryans eklenerek analiz yapılmıştır. Model uyumuna ilişkin araştırmacılar tarafindan genellikle raporlanan (Meydan ve Şeşen, 2015), $\chi^{2}$ (Ki-kare uyum testi), $\chi^{2} / \mathrm{sd}$ (Ki-kare'nin serbestlik derecesine oranı), GFI (İyilik uyum indeksi), NFI (Normlaştırılmış uyum indeksi), IFI (Artırmalı uyum indeksi), TLI (Normlaştırılmamış uyum indeksi), CFI (Karşılaştırmalı uyum indeksi), RMSEA (Yaklaşık hataların karekökü), RMR (Ortalama hataların karekökü) değerlerinin araştırmada da kullanılmasına karar verilmiştir. DFA sonucuna göre, model uyum değerleri; $\chi^{2}=146.180, \chi^{2} / \mathrm{sd}=3.110$, $\mathrm{p}=0.00, \mathrm{GFI}=0.941, \mathrm{NFI}=0.959$, IFI=0.972, TLI=0.960, CFI=0.972, RMSEA=0.076, RMR=0.038 olarak bulunmuş ve elde edilen değerlerin kabul edilebilir düzeyde olduğu sonucuna varılmıştır (Hu ve Bentler, 1999; Kline, 2011; Schermelleh-Engel, Moosbrugger ve Müller, 2003). Bu sonuç ölçeğin dört boyutlu yapısının araştırma örnekleminde doğrulandığına ve ölçeğin yapısal olarak uygun olduğuna ilişkin kanıt sağlamaktadır.

Brandes vd. (1999) tarafından geliştirilen Örgütsel Sinizm Ölçeğinin Türkçeye uyarlama, geçerlik ve güvenirlik çalışmaları Kalağan (2009) tarafından yapılmıştır. Ölçek 13 maddeden ve üç alt boyuttan (bilişsel, duyuşsal ve davranışsal) oluşmaktadır. Yapılan araştırmada, ölçeğe ait Cronbach's Alpha Güvenirlik Katsayısı, bilişsel sinizm için .814, duyuşsal sinizm için .946, davranışsal sinizm için .803, ölçeğin geneli için ise .909 olarak hesaplanmıştır. Ölçeğin orijinali teorik temeller doğrultusunda geliştirilmiş ve öğretmen örnekleminde daha önce uygulanmıştır. Ancak uyarlama çalışmasının üzerinden yaklaşık on yıl geçtiği için tekrar açımlayıcı faktör analizi yapılmıştır. Analiz sonucunda OS12 maddesinin faktör yükünün düşük olduğu (.28), OS5 maddesinin ise farklı boyutlarla ilişkili olduğu (binişik madde) tespit edilmiştir. Daha sonra yapılan DFA'da model uyumu değerlerini iyileştirmek amacıyla farklı boyutlardaki maddelerle ilişkili olduğu için ki-kare değerinin yükselmesine neden olan OS5 ile faktör yükü düşük olan OS12 maddeleri silinmiştir. Ayrıca OS1 ve OS2 ile OS8 ve OS9 maddelerinin hata terimleri arasına kovaryans eklenmiştir. Yapılan bu modifikasyonların ki-kare ve model uyum değerlerine $\mathrm{p}<0.05$ anlamlılık düzeyinde katkısı olduğu görülmüştür. DFA sonucuna göre, model uyum değerleri; $\chi^{2}=107.938, \chi^{2} / \mathrm{sd}=2.768, \mathrm{p}=0.00$, GFI=0.951, NFI $=0.959$, IFI=0.972, $\mathrm{TLI}=0.960, \mathrm{CFI}=0.972, \mathrm{RMSEA}=0.076, \mathrm{RMR}=0.038$ olarak bulunmuş ve elde edilen değerlerin kabul edilebilir düzeyde olduğu sonucuna varılmıştır. Bu sonuç ölçeğin üç boyutlu yapısının araştırma örnekleminde doğrulandığına ve ölçeğin yapısal olarak uygun olduğuna ilişkin kanıt sağlamaktadır. 


\subsection{Verilerin Analizi}

Analiz öncesinde, veri setinde normal dağılımı etkileyen uç değerleri belirlemek için her bir ölçek maddesinin " $z$ " değeri hesaplanmış ve -3 'ten küçük, +3 'ten büyük olan değerler temizlenmiştir (Çokluk, Şekercioğlu ve Büyüköztürk, 2012). Daha sonra çarpıklık-basıklık değerleri hesaplanmış, elde edilen değerlerin $-1,5$ ve $+1,5$ aralığında değiştiği belirlenmiştir. Bu sonuç verilerin normal dağılıma sahip olduğunu göstermektedir (Tabachnick ve Fidell, 2013). Adımsal çoklu regresyon analizi öncesinde analiz için gerekli varsayımlar kapsamında öncelikle veri setindeki bağımsız değişkenlerin (lider-üye etkileşimi ve alt boyutları) değerleri ile bağımlı değişken (örgütsel sinizm) değerlerinin alt setlerindeki varyansların birbirine eşit olduğu (eş varyanslılık) tespit edilmiştir. Daha sonra regresyon analizinde doğrusallık ve normallik varsayımlarını güçleştiren çok yönlü uç değerler olup olmadığı Mahalanobis uzaklıkları kullanılarak test edilmiştir. Değerlerin Mahalanobis uzaklığı için kritik değer olan 13.82'nin altında olmasından dolayı (Pallant, 2005), çok yönlü uç değerin bulunmadığı sonucuna varılmıştır. Verilerin analizi için anlamlılık değeri $\mathrm{p}<.05$ olarak kabul edilmiştir. Verilerin analizi aşamasında değişkenlere ait aritmetik ortalama, standart sapma ve standart hatanın hesaplanması, Pearson Momentler Çarpım korelasyon katsayısının belirlenmesi ve regresyon analizlerinde SPSS 22.0; yap1 geçerliliği için yapılan DFA analizinde ise, AMOS 23.0 programı kullanılmıştır. Algı düzeyleri, 1.00-1.79 (çok düşük), 1.80-2.59 (düşük), 2.60-3.39 (orta), 3.40-4.19 (yüksek) ve 4.20-5.00 (çok yüksek) şeklinde puanlanmaktadır. Güvenirlik çalışmaları kapsamında, Cronbach's Alpha $(\alpha)$ iç tutarlılık katsayıları hesaplanmıştır. Korelasyon katsayısı ile değişkenler arasındaki ilişkinin yönü ve düzeyi belirlenmiştir. Adımsal çoklu regresyon analizi yapılarak bağımsız değişkenlerin bağımlı değişkeni yordama düzeyi belirlenmiştir.

\section{BULGULAR}

\subsection{Değişkenlere Ait Betimsel İstatistikler}

Değişkenlere ait aritmetik ortalama, standart sapma ve standart hata değerleri gibi betimleyici istatistikler Tablo 1'de yer almaktadır.

Tablo 1. Lider-üye etkileşimi ve alt boyutları ile örgütsel sinizme ait aritmetik ortalama, standart sapma, standart hata değerleri

\begin{tabular}{lccc}
\hline Değişkenler & $\bar{X}$ & SS & Std. Hata \\
\hline 1. Lider-Üye Etkileşimi & 3.61 & .85 & .04 \\
2. Duygu & 3.79 & .98 & .05 \\
3. Katk1 & 3.55 & 1.06 & .06 \\
4. Sadakat & 3.48 & .93 & .05 \\
5. Mesleki Sayg1 & 3.64 & 1.05 & .06 \\
6. Örgütsel Sinizm & 2.24 & .77 & .04 \\
\hline
\end{tabular}

Tablo 1'de görüldüğü üzere; lider-üye etkileşiminin geneli ve alt boyutlarına ilişkin öğretmen alg1 düzeyleri görece yüksektir. Öğretmenlerin örgütsel sinizm algıları ise görece düşük düzeydedir. Öğretmenlerin algılarının en yüksek düzeyde olduğu lider-üye etkileşimi alt boyutunun duygu ( $\bar{X}$ $=3.79)$, en düşük algı düzeyinin ise sadakat alt boyutunda olduğu $(\bar{X}=3.48)$ görülmektedir. Başka bir ifadeyle, öğretmenlerin lider-üye etkileşimi ve alt boyutları hakkındaki görüşlerinden, yöneticilerle kurulan ilişkilerin olumlu yönde olduğu; örgütsel sinizm alg1 düzeylerinin düşük olması ise genel anlamda okula yönelik olumlu bir tutum geliştirdikleri şeklinde yorumlanabilir.

\subsection{Değişkenlere Ait Korelasyon Katsayıları}

Değişkenler arasındaki ilişkinin yönünü ve düzeyini gösteren korelasyon katsayıları aşağıda yer alan Tablo 2'de sunulmuştur. 
Tablo 2. Lider-üye etkileşimi ve alt boyutları ile örgütsel sinizme ait korelasyon katsayıları

\begin{tabular}{|c|c|c|c|c|c|c|}
\hline Değişkenler & 1 & 2 & 3 & 4 & 5 & 6 \\
\hline 1. Lider-Üye Etkileşimi & 1 & & & & & \\
\hline 2. Duygu & $.878 * *$ & 1 & & & & \\
\hline 3. Katk1 & $.840 * *$ & $.655^{* *}$ & 1 & & & \\
\hline 4. Sadakat & $.797 * *$ & $.589 * *$ & $.575^{* *}$ & 1 & & \\
\hline 5. Mesleki Sayg1 & $.850 * *$ & $.716 * *$ & $.575 * *$ & $.554 * *$ & 1 & \\
\hline 6. Örgütsel Sinizm & $-.643 * *$ & $-.608 * *$ & $-.517 * *$ & $-.443 * *$ & $-.590 * *$ & 1 \\
\hline
\end{tabular}
$* \mathrm{p}<.05, * * \mathrm{p}<.01, * * * \mathrm{p}<.001$

Tablo 2'deki korelasyon katsayılarına göre, lider-üye etkileşimi ve örgütsel sinizm değişkenleri negatif yönde, anlamlı ve orta düzeyde ilişkilidir $(\mathrm{r}=-.643, \mathrm{p}<.01)$. Lider-üye etkileşiminin duygu $(\mathrm{r}=.608, \mathrm{p}<.01)$, katk1 $(\mathrm{r}=-.517, \mathrm{p}<.01)$, sadakat $(\mathrm{r}=-.443, \mathrm{p}<.01)$ ve mesleki sayg1 $(\mathrm{r}=-.590, \mathrm{p}<.01)$ alt boyutlarına ilişkin öğretmen algılarının, örgütsel sinizmle negatif yönde, anlamlı ve orta düzeyde bir ilişki içerisindedir.

\subsection{Lider-Üye Etkileşiminin Örgütsel Sinizmi Yordaması}

Lider-üye etkileşiminin örgütsel sinizmi yordamasına yönelik yapılan regresyon analizi sonuçları Tablo 3'te sunulmaktadır.

Tablo 3. Lider-üye etkileşiminin örgütsel sinizmi yordamasına yönelik regresyon analizi sonuçları

\begin{tabular}{|c|c|c|c|c|c|c|}
\hline Model & Yordayıcı değişkenler & $\mathbf{B}$ & Std. Hata & $\beta$ & $\mathbf{t}$ & $\mathbf{p}$ \\
\hline \multirow{4}{*}{ 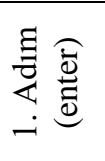 } & (sabit) & 3.949 & .379 & & 10.432 & .000 \\
\hline & Cinsiyet (dummy) & .062 & .080 & .040 & .780 & .436 \\
\hline & Yaş & -.064 & .015 & -.465 & -4.328 & .000 \\
\hline & Kidem & .031 & .016 & .202 & 1.886 & .060 \\
\hline \multirow{5}{*}{ 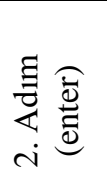 } & (sabit) & 5.027 & .310 & & 16.194 & .000 \\
\hline & Cinsiyet (dummy) & .023 & .063 & .014 & .358 & .721 \\
\hline & Yaş & -.031 & .012 & -.223 & -2.557 & .011 \\
\hline & Kidem & .018 & .013 & .120 & 1.407 & .160 \\
\hline & Lider-üye etkileşimi & -.548 & .038 & -.604 & -14.438 & .000 \\
\hline
\end{tabular}

Bă̆ımlı değişken: Örgütsel sinizm

$\mathrm{R}^{2}$ değişim $=.333, \mathrm{~F}=67.221, \mathrm{p}<.05$

Tablo 3'teki regresyon analizi sonucunda görüldüğü üzere, sonucu etkileyebileceği düşünülen cinsiyet, yaş ve kıdem değişkenleri 1. adımda kontrol altına alınmıştır. 2. adımda lider-üye etkileşiminin örgütsel sinizmin anlamlı bir yordayıcısı olduğu belirlenmiştir $(\beta=-.604 * * *, p<.001)$. Lider-üye etkileşiminde meydana gelen her 10 birimlik artış, örgütsel sinizmde 6.04 birimlik azalma sağlamaktadır. Lider-üye etkileşimi, öğretmenlerin örgütsel sinizm davranışlarının \%33.3’ünü açıklamaktadır $\left(\Delta \mathrm{R}^{2}=.333 ; \mathrm{p}<.001\right)$. Standardize edilmiş regresyon katsayısı incelendiğinde $(\beta)$ liderüye etkileşiminin ( $\mathrm{t}=-14.438, \quad \mathrm{~F}=67.221)$ örgütsel sinizmin anlamlı bir yordayıcısı olduğu görülmektedir. Okullarda lider-üye etkileşimi arttığında, öğretmenlerin örgütsel sinizm davranışları azalmaktadir.

Tablo 3'te yer alan $t$ değerleri incelendiğinde, sabit sayının, yaş ve lider-üye etkileşiminin $p<.05$ düzeyinde anlamlı olduğu görülmektedir. Yapılan adımsal çoklu regresyon analizi sonucu elde edilen denklem; "Örgütsel sinizm=5.027 $+.023^{*}$ Cinsiyet (dummy) $+-.031 *$ Yaş $+.018 *$ Kıdem $+-.548 *$ Liderüye etkileşimi” şeklindedir. Bu formül yardımıyla kişisel değiş̧enler (cinsiyet, yaş ve kıdem) kontrol altına alındığında lider-üye etkileşiminin örgütsel sinizmi yordama düzeyi tahmin edilebilir.

\subsection{Lider-Üye Etkileşiminin Alt Boyutlarının Örgütsel Sinizmi Yordaması}

Lider-üye etkileşiminin alt boyutlarının örgütsel sinizmi yordamasına ilişkin yapılan regresyon analizi sonuçları Tablo 4'te sunulmuştur. 
Tablo 4. Lider-üye etkileşiminin alt boyutlarının örgütsel sinizmi yordamasına yönelik regresyon analizi sonuçları

\begin{tabular}{|c|c|c|c|c|c|c|}
\hline Model & Yordayıcı değișkenler & $\mathbf{B}$ & Std. Hata & $\beta$ & $\mathbf{t}$ & $\mathbf{p}$ \\
\hline \multirow{4}{*}{ 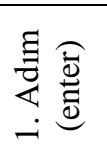 } & (sabit) & 3.949 & .379 & & 10.432 & .000 \\
\hline & Cinsiyet (dummy) & .062 & .080 & .040 & .780 & .436 \\
\hline & Yaş & -.064 & .015 & -.465 & -4.328 & .000 \\
\hline & Kidem & .031 & .016 & .202 & 1.886 & .060 \\
\hline \multirow{7}{*}{ 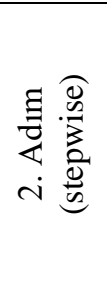 } & (sabit) & 4.913 & .304 & & 16.166 & .000 \\
\hline & Cinsiyet (dummy) & .059 & .064 & .038 & .937 & .350 \\
\hline & Yaş & -.029 & .012 & -.209 & -2.479 & .016 \\
\hline & Kıdem & .017 & .013 & .108 & 1.272 & .204 \\
\hline & Duygu & -.225 & .050 & -.286 & -4.482 & .000 \\
\hline & Mesleki saygi & -.200 & .043 & -.274 & -4.665 & .000 \\
\hline & Katk1 & -.100 & .039 & -.138 & -2.573 & .010 \\
\hline
\end{tabular}

Bă̆ımlı değişken: Örgütsel sinizm

$\mathrm{R}^{2}$ değişim $=.352, \mathrm{~F}=48.294, \mathrm{p}<.05$

Tablo 4'te yer alan adımsal çoklu regresyon analizinde, cinsiyet, yaş ve kıdem, 1. adımda, cinsiyet, yaş ve kıdem değişkenleri kontrol altına alındıktan sonra, 2. adımda stepwise yöntemi ile liderüye etkileşiminin alt boyutları modele eklenmiştir. Örgütsel sinizmin, lider-üye etkileşiminin duygu $\left(\beta=-.286^{* * *}, \mathrm{p}<.001\right)$, mesleki sayg1 $\left(\beta=-.274^{* * *}, \mathrm{p}<.001\right)$ ve katk1 $\left(\beta=-.138^{* *}, \mathrm{p}<.01\right)$ alt boyutlar1 tarafından anlamlı bir şekilde yordandığ 1 belirlenmiştir. Sadakat alt boyutunun ise örgütsel sinizmin anlamlı bir yordayıcısı olmadığı ve bu nedenle stepwise yöntemi ile çıkarıldığı görülmektedir.

Lider-üye etkileşiminin duygu alt boyutundaki her 10 birimlik artış, örgütsel sinizmde 2.86 birimlik bir azalma meydana getirmektedir. Örgütsel sinizmin \%30.1'i lider-üye etkileşiminin duygu alt boyutu tarafından açıklanmaktadır $\left(\Delta \mathrm{R}^{2}=.301 ; \mathrm{p}<.001\right)$. Lider-üye etkileşiminin mesleki saygı alt boyutu örgütsel sinizmdeki toplam varyansın $\% 4.1$ 'ini açıklamaktadır $\left(\Delta \mathrm{R}^{2}=.041 ; \mathrm{p}<.001\right)$. Örgütsel sinizmin \%1.0'i ise lider-üye etkileşiminin katkı alt boyutu tarafından açıklanmaktadır $\left(\Delta \mathrm{R}^{2}=.010\right.$; $\mathrm{p}<.01)$. Standardize edilmiş regresyon katsayısı incelendiğinde $(\beta)$ lider-üye etkileşiminin duygu $(\mathrm{t}=-$ 4.482, $\mathrm{F}=58.962)$, mesleki sayg1 $(\mathrm{t}=-4.665, \mathrm{~F}=55.751)$ ve katk1 $(\mathrm{t}=-2.573, \mathrm{~F}=48.294)$ alt boyutlarının, örgütsel sinizmin anlamlı bir yordayıcısı olduğu görülmektedir. Elde edilen bu bulgular, lider-üye etkileşiminin duygu, mesleki sayg1 ve katkı alt boyutlarındaki artışı, öğretmenlerin örgütsel sinizm davranışlarını azalttığını göstermektedir.

Tablo 4'teki t değerleri incelendiğinde, sabit sayının, yaş, duygu, mesleki saygı ve katkı alt boyutlarının $\mathrm{p}<.05$ düzeyinde anlamlı olduğu görülmektedir. Yapılan adımsal çoklu regresyon analizi sonucu elde edilen denklem; "Örgütsel Sinizm $=4.913+.059 *$ Cinsiyet (dummy) $+-.029 *$ Yaş + $.017 *$ Kıdem $+-.225 *$ Duygu $+-.200 *$ Mesleki sayg1 $+-.100 *$ Katkı" şeklindedir. Bu formülden yararlanılarak, kişisel değişkenler (cinsiyet, yaş ve kıdem) kontrol altına alındığında lider-üye etkileşiminin duygu, mesleki saygı ve katkı alt boyutlarının örgütsel sinizmi yordama düzeyi tahmin edilebilir.

\section{TARTIŞMA ve SONUÇ}

Okullarda lider-üye etkileşimi ile örgütsel sinizm ilişkisinin incelendiği araştırma sonucunda, öğretmenlerin lider-üye etkileşiminin hem geneli hem de duygu, katkı, sadakat ve mesleki saygı alt boyutları için kısmen yüksek düzeyde algıya sahip oldukları belirlenmiştir. Lider-üye etkileşimine yönelik öğretmen algılarının olumlu olmasında, okul yöneticileri ile etkileşim içerisinde bulunmaları, okulla ilgili faaliyetlerde aktif rol almaları ve karar alma sürecine katılmaları gibi unsurların etkili olduğu düşünülmektedir. Nitekim Cerit (2012), yönetici ve öğretmenler arasındaki etkileşimin yükssek olmasının, karşılıklı güven oluşturacağını ve bilgi alışverişini arttıracağını ifade etmiştir. Ayrıca ögretmenlerin okulla ilgili yapılacak faaliyetlerde aktif rol alacakları ve rollerinin gereklerini yerine getirmek için daha fazla çaba gösterecekleri yönünde görüş belirtmiştir. Bu bulguyu destekler nitelikte benzer bir bulguya, Kavuncu (2019) tarafindan yürütülen araştırma sonucunda rastlanmış; öğretmenlerin duygu, katkı ve mesleki saygı alt boyutlarına ilişkin algılarının kısmen yüksek düzeyde, sadakat alt boyutuna yönelik algılarının ise orta düzeyde olduğu tespit edilmiştir. Okullarda lider-üye 
etkileşimi ile ilgili olarak öğretmen görüşlerinin incelendiği, Runhaar, Konermann ve Sanders (2013) ile Öztürk ve Şahin (2017) tarafından yürütülen araştırmaların sonucunda da bu araştırmadan elde edilen sonuca benzer şekilde, öğretmenlerin yöneticilerle etkileşimlerinin yüksek düzeyde olduğu bulgusuna ulaşılmıştır. Diğer bir deyişle, öğretmenler yöneticilerle kurdukları ilişkilerin olumlu yönde olduğu görüşünü belirtmişlerdir.

Araştırma sonucundan elde edilen diğer bir bulguya göre, öğretmenlerin örgütsel sinizm algıları kısmen düşük düzeydedir. Uzun ve Ayık (2016) tarafından yürütülen bir araştırmadan elde edilen bulguya göre, öğretmenlerin örgütsel sinizm düzeyleri incelenmiş ve öğretmenlerin örgütsel sinizm algılarının kısmen düşük düzeyde olduğu belirlenmiştir. Öğretmenlerin örgütsel sinizm algılarının düşük olduğu bulgusu Güçlü, Kalkan ve Dağlı (2017) tarafindan yapılan araştırma sonucuyla da benzerlik göstermektedir. Nitekim araştırma sonucunda da öğretmenlerin okula yönelik genel olarak olumlu bir tutuma sahip oldukları ve dolayısıyla sinizm davranışlarının daha az gösterildiği tespit edilmiştir. $\mathrm{Bu}$ sonuç, öğretmenlerin okul içerisinde yapılan iş ve işlemlerde dürüst ve adil davranılmasından, çalıșanlar arasında güvene dayalı ilișkilerin olușturulmasından ve bu nedenle okulla ilgili olumlu duygulara sahip olmalarından kaynaklı olabilir. Çünkü okul yönetiminin aldığı kararlarda ve uygulamalarda şeffaf olmadığını düşünen öğretmenlerin, güven düzeyi azalmakta ve sinizm davranışları artmaktadır (Helvacı ve Çetin, 2012). Söz konusu bu durumda ise, öğretmenlerin okula ilişkin olumsuz tutum ve duyguya sahip olmaları nedeniyle performansları azalmaktadır (Sağır ve Oğuz, 2012). Öğretmenlerin performansındaki bu düşüşün, eğitim-öğretim faaliyetlerine yansımasının da olumsuz yönde olacağı ileri sürülebilir.

Lider-üye etkileşimi ve örgütsel sinizm ilişkisini belirlemeye yönelik yapılan korelasyon analizi sonucuna göre, lider-üye etkileşimi ve örgütsel sinizm, orta düzeyde, negatif yönde, anlamlı bir ilişkiye sahiptir. Diğer bir ifadeyle, okullarda yönetici kademesinde bulunanlar ve öğretmenler arasındaki etkileşimin yüksek düzeyde olması, öğretmenlerin örgütsel sinizm davranışlarını daha az göstermelerini sağlayacaktır. Benzer bir bulguya Gültekin (2014) tarafından yapılan bir araştırma sonucunda da rastlanmaktadır. Söz konusu araştırmada; lider-üye etkileşimi ve örgütsel sinizm ilişkisinin kısmen yüksek düzeyde, negatif yönde, anlamlı olduğu belirlenmiştir. Bu sonuç, lider-üye etkileşiminin niteliğinin düşük olmasının çalışanların örgüte yönelik sinizm davranışları gösterme eğiliminde olacaklarını göstermektedir. Lider-üye etkileşimi ve örgütsel sinizm ilişkisini belirlemek amacıyla Davis ve Gardner (2004) tarafından yapılan bir araştırmada, örgütsel ortamda adalet, dürüstlük, doğruluk ve samimiyetin olmadığı durumlarda lider-üye etkileşiminin düşük olacağ 1 ve bunun sonucunda sinizm davranışlarının daha fazla sergileneceği ifade edilerek, lider-üye etkileşiminin örgütsel sinizmi azaltıcı bir rolü olduğuna atıfta bulunulmuştur.

Lider-üye etkileşiminin örgütsel sinizmi yordama düzeyini belirlemek için regresyon analizi yapılmış, ilk modelde lider-üye etkileşimi toplam puan üzerinden değerlendirilmiştir. Birinci adımda cinsiyet, yaş ve kıdem kişisel değişkenleri kontrol altına alındıktan sonra, ikinci adımda lider-üye etkileşimi modele eklenmiş ve lider-üye etkileşimin örgütsel sinizmi negatif yönde, anlamlı düzeyde yordadığı tespit edilmiştir. Bu sonuç, okullarda lider-üye etkileşiminin kalitesinin yükseltilmesinin, öğretmenlerin sinizm davranışlarını azaltacağını göstermektedir. Nitekim, lider-üye etkileşimi ve sinizm ilişkisine yönelik olarak Wanous, Reichers ve Austin (1994), sinizm davranışlarının genellikle lidere karşı gösterildiğini; Bommer, Rich ve Rubin (2005) ise lider-üye etkileşiminin niteliğinin düşük olmasının sinizmin örgütsel nedenlerinden biri olduğunu ifade ederek bu araştırmadan elde edilen liderüye etkileşiminin sinizm davranışlarını azalttığı bulgusunu desteklemektedirler. Eğitim bağlamında değerlendirildiğinde, öğretmenlerin yöneticilerle etkileşimlerinin yüksek düzeyde olması, okula ve çalışanlara karşı olumlu bir tutum oluşturulmasına ve performanslarının da bu yönde sergilenmesine katk1 sağlayacaktır. Bu durumun öğretmenlerin bireysel olarak olumlu bir tutum sergileyerek okula bağlılıklarının arttırmanın yanı sıra, okulun misyon ve vizyonunun etkin bir şekilde gerçekleştirilmesinde önemli olduğunu söylemek mümkündür.

Araştırmada, lider-üye etkileşiminin sadakat alt boyutu dışındaki duygu, mesleki saygı ve katkı alt boyutlarının örgütsel sinizmi negatif yönde, anlamlı bir şekilde yordadığı sonucuna varılmıştır. $\mathrm{Bu}$ sonuç öğretmenlerin ve yöneticilerin etkileşim içerisinde bulunmalarının, ortak amaç doğrultusunda okulu geliştirmeye yönelik faaliyetlere katkı sunmalarının ve mesleki yeterliklerine yönelik olumlu algıya sahip olmalarının, örgütsel sinizm davranışlarını azaltacağı şeklinde yorumlanabilir. Lider-üye etkileşiminin kalitesinin ve düzeyinin yükseltilmesi, çalışanların daha yüksek performans göstermeleri ve performanslarını olumsuz yönde etkileyebileceği düşünülen unsurların azaltılması üzerinde olumlu 
etkiye sahiptir. Bu bağlamda, çalışanların performanslarını olumsuz yönde etkileyen ve örgütte yaşanan hayal kırıklıklarının, adil olmayan süreçlerin bir sonucu (Wilkerson, Evans ve Davis, 2008), örgüte karş1 gösterilen olumsuz tutum ve inanç (Dean, Brandes ve Dharwadkar, 1998) şeklinde ifade edilen örgütsel sinizmin, lider-üye etkileşiminin geliştirilmesiyle azaltılabilecek olumsuz unsurlardan biri olduğu ifade edilebilir.

Okul yöneticilerinin öğretmenlerle etkileşim içerisinde bulunmaları, sinizm davranışı gösterme eğiliminde olan öğretmenleri bu eğilimden uzaklaştırmak için çaba göstermeleri gerekmektedir. Bunun için, katılımlı bir yönetim anlayışı benimsenerek, öğretmenlerin düşüncelerini rahat bir şekilde ifade etmeleri ve karar alma sürecine aktif olarak katılımları sağlanmalıdır. Bu süreçte, öğretmenlerin hem yöneticilerle hem de diğer meslektaşlarıyla güven, saygı ve sadakat temeline dayalı ilişkiler kurmaları önemli görülmektedir. Araştırmacılara yönelik öneri olarak, lider-üye etkileşimi ve örgütsel sinizmle ilişkili olduğu düşünülen duygusal emek, tükenmişlik, örgütsel bağl1lık vb. değişkenler arasındaki ilişki araştırılabilir. Değişkenlerle ilgili ayrıntılı bilgi elde etmek amacıyla nitel araştırmalar yapılabilir. Ayrıca karma desende araştırmalar yapılarak, nicel ve nitel sonuçlar karşılaştırmalı bir şekilde sunulabilir. Araştırma Gaziantep ili ve ortaokul örneklemi ile sınırlıdır. Farklı şehirlerde, örneklemlerde ve eğitim kademelerinde de araştırmalar yapılarak sonuçlar arasındaki benzerlikler ve farklılıklar ortaya çıarılabilir.

\section{KAYNAKÇA}

Abraham, R. (2000). Organizational cynicism: Bases and consequences. Genetic, Social, and General Psychology Monographs, 126(3), 269-292.

Alev, S. (2018). Öğretmenlerin genel öz yeterlilik algıları ile duygusal emek davranışları arasındaki ilişkinin incelenmesi: İzlenim yönetimi taktiklerinin aracllık rolü. Yayımlanmamış doktora tezi, Gaziantep Üniversitesi Eğitim Bilimleri Enstitüsü, Gaziantep.

Andersson, L. M., \& Bateman, T. S. (1997). Cynicism in the workplace: Some causes and effects. Journal of Organizational Behavior 18(5), 449-469.

Balcı, A. (2016). Sosyal bilimlerde araştırma: Yöntem, teknik ve ilkeler. Ankara: Pegem Akademi Yayıncılık.

Baş, T., Keskin, N., \& Mert, İ. S. (2010). Lider üye etkileşimi (LÜE) modeli ve ölçme aracının Türkçe'de geçerlik ve güvenilirlik analizi. Ege Akademik Baklş, 10(3), 1013-1039.

Bolat, İ. (2011). Öz yeterlilik ve lider üye etkileşimi ilişsisi: Göze girme davranışları ve güç mesafesinin etkisi. Detay Yayıncılık, Ankara.

Bommer, W.H., Rich, G.A., \& Rubin, R.S. (2005). Changing attitudes about change: Longitudinal effects of transformational leader behavior on employee cynicism about organizational change. Journal of Organizational Behavior, 26(7), 733-753.

Brandes, P. (1997). Organizational cynicism: It's nature, antecedents, and consequences. Unpublished Doctoral Dissertation, Division of Research and Advanced Studies of the University of Cincinnati, USA.

Brower, H. H., Schoorman, F. D., \& Tan, H. H. (2000). A model of relational leadership: The integration of trust and leader-member exchange. The Leadership Quarterly, 11(2), 227-250.

Burton, J. P., Sablynski, C. J., \& Sekiguchi, T. (2008). Linking justice, performance, and citizenship via leadermember exchange. Journal of Business and Psychology, 23(1-2), 51-61.

Cerit, Y. (2012). Lider üye etkileşimi ile öğretmenlerin performansları arasındaki ilişki. Balıkesir Üniversitesi Sosyal Bilimler Enstitüsü Dergisi, 15(28), 33-46.

Cole, M. S., Bruch, H., \& Vogel, B. (2006). Emotion as mediators of the relations between perceived supervisor support and psychological hardiness on employee cynicism. Journal of Organizational Behavior, 27, 463484.

Çokluk, Ö., Şekercioğlu, G., \& Büyüköztürk, Ş. (2012). Sosyal bilimler için çok değişkenli SPSS ve LISREL uygulamaları. Ankara: Pegem Akademi Yayıncılık.

Davis, W. D., \& Gardner, W. L. (2004). Perceptions of politics and organizational cynicism: An attributional and leader-member exchange perspective. The Leadership Quarterly, 15(4), 439-465. 
Dean, J. W., Brandes, P., \& Dharwadkar, R. (1998). Organizational cynicism. Academy of Management Review, 23, 341-352.

Deluga, R. J. (1994). Supervisor trust building, leader-member exchange and organizational citizenship behaviour. Journal of Occupational and Organizational Psychology, 67(4), 315-326.

Dienesch, R. M., \& Liden, R. C. (1986). Leader-member exchange model of leadership: A critique and further development. Academy of Management Review, 11(3), 618-634.

Erdogan, B., Liden, R. C., \& Kraimer, M. L. (2006). Justice and leader-member exchange: The moderating role of organizational culture. Academy of Management Journal, 49(2), 395-406.

Field, A. (2009). Discovering statistics using SPSS. Dubai: Oriental Press.

Graen, G. B., \& Uhl-Bien, M. (1995). Development of leader-member exchange (LMX) theory of leadership over 25 years: Applying a multi-level multi-domain perspective. Leadership Quarterly, 6(2), 219-247.

Göksel, A., \& Aydıntan, B. (2012). Lider-üye etkileşimi düzeyinin örgütsel bağlılık üzerine etkisi: Görgül bir araştırma. Süleyman Demirel Üniversitesi İktisadi ve İdari Bilimler Fakültesi Dergisi, 17(2), 247-271.

Guastello, S. J., Rieke, M. L., Guastello, D. D., \& Billings, S. W. (1992). A study of cynicism, personality, and work values. The Journal of Psychology, 126(1), 37-48.

Güçlü, N., Kalkan, F., \& Dağlı, E. (2017). Mesleki ve teknik ortaöğretim okulu öğretmenlerin algılarına göre okul müdürlerinin liderlik stilleri ile örgütsel sinizm arasındaki ilişki. Gazi Üniversitesi Gazi Eğitim Fakültesi Dergisi, 37(1), 177-192.

Gültekin, S. (2014). Psikolojik sözleşme ihlali ile örgüte karşı sinik tutum arasındaki ilişkide lider-üye etkileşiminin aracılık etkisi. Yayımlanmamış doktora tezi, Hacettepe Üniversitesi Sosyal Bilimler Enstitüsü, Ankara.

Gürler, M. (2018). Öğretmenlerin lider-üye etkileşimi ile işle bütünleşme ilişkisinde çalışan sesliliğinin aracılık etkisinin incelenmesi. Yayımlanmamış doktora tezi, Anadolu Üniversitesi Eğitim Bilimleri Enstitüsü, Eskişehir.

Helvacı, M. A., \& Çetin, A. (2012). İlköğretim okullarında görev yapan öğretmenlerin örgütsel sinizm düzeylerinin belirlenmesi (Uşak ili örneği). Turkish Studies, 7(3), 1475-1497.

Hu, L., \& Bentler, P. M. (1999). Cutoff criteria for fit indexes in covariance structure analysis: Conventional criteria versus new alternatives. Structural Equation Modelling: A Multidisciplinary Journal, 6(1), 1-55.

Johnson, J. L., \& O'Leary-Kelly A. M. (2003). The effects of psychological contract breach and organizational cynicism: Not all social exchange violations are created equal. Journal of Organizational Behavior, 24, 627-647.

Kalağan, G. (2009). Araştırma görevlilerinin örgütsel destek alglları ile örgütsel sinizm tutumları arasındaki ilişki. Yayımlanmamış yüksek lisans tezi, Akdeniz Üniversitesi Sosyal Bilimler Enstitüsü, Antalya.

Kalağan, G., \& Aksu, M. B. (2010). Organizational cynicism of the research assistants: A Case of Akdeniz University. Procedia-Social and Behavioral Sciences, 2(2), 4820-4825.

Karacaoğlu, K., \& İnce, A. G. F. (2013). Pozitif örgütsel davranışın örgütsel sinizm üzerindeki etkileri: Kayseri ilindeki imalat sanayi işletmelerinde bir uygulama. Süleyman Demirel Üniversitesi İktisadi ve İdari Bilimler Fakültesi Dergisi, 18(1), 181-202.

Karasar, N. (2015). Bilimsel araştırma yöntemleri (28. basım). Ankara: Nobel Akademi Yayıncılık.

Karcıoğlu, F., \& Kahya, C. (2011). Lider-üye etkileşimi ve çatışma yönetim stili ilişkisi. Atatürk Üniversitesi Sosyal Bilimler Enstitüsü Dergisi, 15(2), 337-352.

Kaşl1, M. (2009). Otel işletmelerinde işgörenlerin kişilk özellikleri, lider-üye etkileşimi ve tükenmişlik ilişkisinin incelenmesi. Balıkesir Üniversitesi Sosyal Bilimler Enstitüsü, Balıkesir.

Kavuncu, M. (2019). Lider-üye etkileşimi ile öğretmenlerin örgütsel vatandaşlık davranışları arasındaki ilişki. Yayımlanmamış yüksek lisans tezi, İstanbul Sabahattin Zaim Üniversitesi Sosyal Bilimler Enstitüsü, İstanbul.

Kline, R. B. (2011). Principles and practice of structural equation modeling. New York, NY: Guilford. 
Lee, J. (2005). Effects of leadership and leader-member exchange on commitment. Leadership \& Organization Development Journal, 26(8), 655-672.

Liden, R. C., \& Maslyn, J. M. (1998). Multidimensionality of leader-member exchange: An empirical assessment through scale development. Journal of Management, 24(1), 43-72.

Loi, R., Chan, K. W., \& Lam, L. W. (2014). Leader-member exchange, organizational identification, and job satisfaction: A social identity perspective. Journal of Occupational and Organizational Psychology, 87(1), 42-61.

Martin, R., Thomas, G., Charles, K., Epitropaki, O., \& McNamara, R. (2005). The role of leader-member exchanges in mediating the relationship between locus of control and work reactions. Journal of Occupational and Organizational Psychology, 78(1), 141-147.

Maslyn, J. M., \& Uhl-Bien, M. (2001). Leader-member exchange and its dimensions: Effects of self-effort and other's effort on relationship quality. Journal of Applied Psychology, 86(4), 697-708.

Meydan, C. H., \& Şeşen, H. (2015). Yapısal eşitlik modellemesi AMOS uygulamaları. Ankara: Detay Yayıncıl1k.

Nartgün, S. S., \& Kartal, V. (2013). Öğretmenlerin örgütsel sinizm ve örgütsel sessizlik hakkındaki görüşleri. Bartın Üniversitesi Eğitim Fakültesi Dergisi, 2(2), 47-67.

Neves, P. (2012). Organizational cynicism: Spillover effects on supervisor-subordinate relationships and performance. The Leadership Quarterly, 23(5), 965-976.

Öztürk, N., \& Şahin, S. (2017). Eğitim örgütlerinde örgüt kültürü ve öğretmen liderliği: Lider-üye etkileşiminin aracıl1k rolü. Ilköğretim Online, 16(4), 1451-1468.

Özutku, H., Ağca, V., \& Cevrioğlu, E. (2008). Lider-üye etkileşim teorisi çerçevesinde, yönetici-ast etkileşimi ile örgütsel bağlılık boyutları ve iş performansı arasındaki ilişki: Ampirik bir inceleme. Atatürk Üniversitesi Iktisadi ve İdari Bilimler Dergisi, 22(2), 193-210.

Pallant, J. (2005). SPSS survival manual: A step by step guide to data analysis using SPSS for Windows. Australia: Allen \& Unwin.

Polat, M., \& Meydan, C. H. (2010). Örgütsel özdeşleşmenin sinizm ve işten ayrılma niyeti ile ilişkisi üzerine bir araştırma. Savunma Bilimleri Dergisi, 9(1), 145-172.

Reichers, A. E., Wanous, J. P., \& Austin, J. T. (1997). Understanding and managing cynicism about organizational change. Academy of Management Perspectives, 11(1), 48-59.

Runhaar, P., Konermann, J., \& Sanders, K. (2013). Teachers' organizational citizenship behaviour: Considering the roles of their work engagement, autonomy and leader-member exchange. Teaching and Teacher Education, 30, 99-108.

Sağır, T., \& Oğuz, E. (2012). Öğretmenlere yönelik örgütsel sinizm ölçeğinin geliştirilmesi. International Journal of Human Sciences, 9(2), 1094-1106.

Settoon, R. P., Bennett, N., \& Liden, R. C. (1996). Social exchange in organizations: Perceived organizational support, leader-member exchange, and employee reciprocity. Journal of Applied Psychology, 81(3), 219227.

Schermelleh-Engel, K., Moosbrugger, H., \& Müller, H. (2003). Evaluating the fit of structural equation models: Tests of significance and descriptive goodness-of-fit measures. Methods of Psychological Research Online, 8(2), 23-74.

Schriesheim, C. A., Castro, S. L., \& Cogliser, C. C. (1999). Leader-member exchange (LMX) research: A comprehensive review of theory, measurement, and data-analytic practices. The Leadership Quarterly, 10(1), 63-113.

Stanley, D. J., Meyer, J. P., \& Topolnytsky, L. (2005). Employee cynicism and resistance to organizational change. Journal of Business and Psychology, 19(4), 429-459.

Tabachnick, B. G., \& Fidell, L. S. (2013). Using multivariate statistics (sixth ed.). Pearson, Boston.

Uzun, T., \& Ayık, A. (2016). Okul müdürlerinin iletişim becerileri ile öğretmenlerin genel ve örgütsel sinizm tutumları arasındaki ilişkilerin incelenmesi. Mersin Üniversitesi Eğitim Fakültesi Dergisi, 12(2), 672-688. 
Wanous, J. P., Reichers, A. E., \& Austin, J. T. (1994). Organizational cynicism: An initial study. Academy of Management Best Papers Proceedings, 269-273.

Wilkerson, J. M., Evans, W. R., \& Davis, W. D. (2008). A test of coworkers' influence on organizational cynicism, badmouthing, and organizational citizenship behavior. Journal of Applied Social Psychology, 38(9), 22732292.

Yu, D., \& Liang, J. (2004). A new model for examining the leader-member exchange (LMX) theory. Human Resource Development International, 7(2), 251-264. 